\title{
SKILLED LABOUR SHORTAGE IN THE BUILDING CONSTRUCTION INDUSTRY WITHIN THE CENTRAL REGION
}

\author{
Benjamin Boahene AKOMAH ${ }^{1}$, Laud Kwamina AHINAQUAH ${ }^{2}$, \\ Zakari MUSTAPHA ${ }^{3}$ \\ ${ }^{1,2,3}$ Department of Building Technology, School of Engineering, Cape Coast Technical \\ University (CCTU), Cape Coast, Ghana \\ Corresponding author's email: mustapha.zakari@cctu.edu.gh
}

\begin{abstract}
Skilled labour shortage is the shortfall of workforce in specific trades or shortage of workforce with requisite skills. The paper seeks to identify areas where there are skilled labour shortages in the building construction industry within the Central Region. A survey research approach was employed to get the study population that consisted of project managers, site engineers, site foremen and engineers working with contactors. Questionnaires were designed based on the research specific objectives and used as the main instrument for data collection. Findings from the study revealed that the shortage of skilled manpower was from painters and decorators, electricians and tile workers. Further findings showed that skilled labour shortage was caused by socio-economic conditions, external forces, job attractiveness, job characteristics, job satisfaction, industry limitations and personal factors. Employees should be encouraged to develop their trade competences and change their attitude to work, while employers should build their manpower base through training.
\end{abstract}

Keywords: Construction projects, Ghana, performance, productivity, skilled workforce, project delivery.

\section{INTRODUCTION}

Skilled labour plays a very important role in the success of every construction project and stands tall in the advent of sophistication and technology in building construction project delivery. Skilled manpower as pointed out by Gudiene et al. (2013) is considered to be one of the critical factors of production in construction projects. As activities on site are largely reliant on skilled workforce (Mackenzie, Kilpatrick, \& Akintoye, 2000), any shortage has a negative implication for the construction industry. The construction industry in Ghana alone provided employment for about $2.3 \%$ of active employees (Amankwa, 2003). The Growth Domestic Product (GDP) recorded by the industry in 2018 was $7.2 \%$ (Ofori, 2018), which showed that the percentage growth could be improved further with highly skilled manpower. Carliner (1998) indicated that contractors found it difficult to attract the requisite skilled labour for their numerous projects due to the high demand for such workforce. The problem is even compounded because many of the available skilled workforce have a low level of skills in their respective trade areas 
(Erkelens \& van Egmond, 2007). However, the extent of shortage differs from trade to trade and this has put pressure on project delivery in the country. The study seeks to identify the trade areas with shortage of manpower and come out with some needed characteristics that should be possessed by skilled employees in the region.

\section{SKILLED LABOUR}

The construction industry is considered one of the largest industries in the world (Ahmed et al., 2008). It is an essential developmental component of a nation's economy (Oseghale \& Ata, 2008), but its performance depends so much on skilled labour. Skilled labour adequacy and availability continue to be a major challenge in the industry. According to Healy, Mavromaras, \& Sloane (2011), skilled labour shortage is an intricate phenomenon, which influences the performance of construction activities. Windapo (2016) postulated that most project failures were due to inadequate skilled manpower. She said, sometimes it is not the inadequacy, but getting the workforce with cutting-edge skill. Several authors (SLIM Report, 2002; Dainty, Ison, \& Root, 2004; Tarnoki, 2002; Lill, 2004; Olsen, Tatum \& Defnallet, 2012; Oseghale, Abiola-Falemu \& Oseghale, 2015) attributed the shortage of skilled labour to the increasing number of aging employees, lack of sustained training and training policies, increasing number of projects, the bad public perception about construction workers and the unappealing nature of the industry to the youth who were in the majority. Bennett \& McGuinness (2009), on the other hand, attributed the shortage of skilled labour to the negative image of the industry. It is considered one of the high risks and accident-prone industry. Rasool and Botha (2011), however, believed that the factors were numerous.

Yusof \& Misnan (2009) maintained that, as a labour-intensive industry, it depended heavily on human capital for sustenance. Ward (1979) indicated that each skilled labour employed made a direct economic contribution not only to a particular sector, but to the country as a whole. Therefore, any shortage that stifles construction activities will negatively impact the national economy. Barnow, Trutko, \& Piatak (2013) defined skilled labour shortage as a "mismatch between worker qualifications and available jobs". The current picture of skilled labour shortage in the region shows that there is imbalance between supply and demand. Othman (2014) stated that the shortage of skilled labour had serious consequences on construction productivity and the general health of construction projects (Baloyi $\&$ Bekker, 2011) and, therefore, any attempt to find a solution should be swiftly taken.

\section{METHODOLOGY}

A survey method of data collection was used in the study. Saunders, Lewis and Thornhill (2009) indicated that a survey method is an economic way of collecting data and helps in the collection of large volumes of data as compared to other methods. Questionnaire was adopted as an instrument (Sarantakos, 2005).

The questionnaire had four sections, and each section was structured in a four-point Likert scale. The structured questions were used to solicit more 
responses from respondents. Close-ended questions were also used to test the rating of various attributes and to help reduce the number of related responses in order to obtain more varied responses. A total population of 110 included project managers, site engineers, site foremen and engineers of the various contractors working in the region. The questionnaires were administered to 110 respondents. Out of 110 questionnaires administered, 90 were retrieved, which represented $82 \%$. The data obtained were analysed using descriptive statistics and Statistics Package for Social Sciences (SPSS). The results were presented in tables. The $p$-value of the Kaiser-Meyer-Olkin (KMO) was calculated to determine the appropriateness of the factor model. Eigen values were used to determine the main causes of shortage. Rotated component matrix was finally used to classify the causes under appropriate factors.

\section{AREAS OF SKILLED LABOUR SHORTAGE}

Table 1 shows that painters and decorators, electricians and tile workers were the professions that were in shortage in the construction industry within the Central Region, with average indices of $1.74,1.70$, and 1.70 respectively and were ranked $1^{\text {st }}$ and $2^{\text {nd }}$. On the other hand, HVAC installers and pipe fitters classified as the skilled labour force that can easily be sourced occupied the $11^{\text {th }}$ and $12^{\text {th }}$ position with average indices of 1.44 and 1.40. The result in the study is confirmed by NH Business Review (2018) that says skilled workers like electricians and plumbers are hard to come by. The construction industry, because of its unique nature, requires high level skilled capacity to fulfil the requirements of clients (Enshassi, Mohamed \& Ekarriri, 2009).

Table 1. Skilled Labour Shortage

\begin{tabular}{lcc}
\hline SKILLED LABOUR & AVERAGE INDEX & RANK \\
\hline Painters/decorators & 1.74 & 1 \\
Electricians & 1.70 & 2 \\
Tile workers & 1.70 & 2 \\
Steel benders & 1.69 & 4 \\
Plumbers & 1.65 & 5 \\
Glaziers & 1.65 & 5 \\
Masons & 1.61 & 7 \\
Roofers & 1.60 & 8 \\
Land scraper & 1.55 & 9 \\
Carpenters & 1.55 & 9 \\
HVAC installer technician & 1.40 & 11 \\
Pipe fitter & 1.44 & 12 \\
\hline
\end{tabular}

\section{CAUSES OF SKILLED LABOUR SHORTAGE}

Table 2 shows that the $\mathrm{p}$-value of the $\mathrm{KMO}=0.518$ is greater than the significance level of 0.05 for the measure of sampling adequacy; thus, the factor model is appropriate. The Bartlett's test of sphericity will be rejected at the 
significance level of 0.05 . Thus, the correlation matrix is not an identity matrix since the $p$-value is less than 0.05 .

Table 2. KMO and Bartlett's Test of Sphericity

\begin{tabular}{lll}
\hline \multicolumn{2}{l}{ Kaiser-Meyer-Olkin Measure of Sampling Adequacy } & 0.518 \\
& Approx. Chi-Square & 625.483 \\
Bartlett's Test of Sphericity & Df & 210 \\
& Sig. & 0.000 \\
\hline
\end{tabular}

\section{Variance Explained}

Table 3 shows that there are eight (8) factors/components that indicate the main causes of shortage of skilled labour with eigenvalues greater than one. The first factor/component explains $15.914 \%$ of the variation in the causes of skilled labour shortage. The second factor/component explains $13.364 \%$ of the variation, which is unaccounted for by the first factor. All the eight factors/components combined explain $73.13 \%$ of the total variability in the causes of skilled labour shortage.

Table 3. Total Variance Explained

\begin{tabular}{lllllcc}
\hline \multicolumn{2}{c}{ Component Initial Eigenvalues } & \multicolumn{4}{c}{ Extraction Sums of Squared Loadings } \\
& Total & \multicolumn{2}{c}{ \% of VarianceCumulative } & \% Total & \% of VarianceCumulative \% \\
\hline 1 & 3.342 & 15.914 & 15.914 & 3.342 & 15.914 & 15.914 \\
2 & 2.806 & 13.364 & 29.278 & 2.806 & 13.364 & 29.278 \\
3 & 2.248 & 10.706 & 39.984 & 2.248 & 10.706 & 39.984 \\
4 & 1.851 & 8.816 & 48.800 & 1.851 & 8.816 & 48.800 \\
5 & 1.508 & 7.181 & 55.981 & 1.508 & 7.181 & 55.981 \\
6 & 1.299 & 6.184 & 62.165 & 1.299 & 6.184 & 62.165 \\
7 & 1.184 & 5.637 & 67.802 & 1.184 & 5.637 & 67.802 \\
8 & 1.119 & 5.329 & 73.131 & 1.119 & 5.329 & 73.131 \\
\hline
\end{tabular}

Depending on the design of the study, a factor/component should have at least three variables (Tabachnick \& Fidell, 2007). Rotated factors that have two or fewer variables should be interpreted with caution. A factor/component with two variables is only considered reliable when the variables are highly correlated with each other $(r>0.70)$, but fairly uncorrelated with other variables. Factor/component 5 is rejected since the variables do not meet the stated criteria. Using factor loadings greater than 0.4, it can be seen from Table 4 that the variables (economic change, high education level, increase demand for craft workers and lack of job security) are highly loaded on factor 1 . These variables are collectively named socio-economic conditions. Considering factor 2, variables such as dissatisfaction 
with labour organisation, geographical location, new technology and poor training are highly loaded on factor 2 . Hence, these variables are collectively classified as external forces. Furthermore, union and open shop changes, and a lack of interest by the youth are highly loaded on factor 3 . Hence, factor 3 is categorised as job attractiveness. In turn, ageing workforce and changes in skill requirement are highly loaded on factor 4. Hence, these variables are collectively classified as job characteristics. Educational changes and images, irregular and low remuneration, and low motivation are highly loaded on factor 6 and categorised as job satisfaction. Poor construction industry image, poor education and low number of new entrants are highly loaded on factor 7 and grouped as industry limitations. Finally, high mobility and poor treatment are highly loaded on factor 8 and named as personal factors. The causes of skilled labour shortage in the building construction industry can be attributed to socio-economic conditions, external forces, job attractiveness, job characteristics, job satisfaction, industry limitations and personal factors.

Willow (1998) indicated that economic recession or bad seasons of construction businesses account for a substantial shortage in the construction industry. Most skilled workers lose their jobs and, in an attempt, to overcome the pressure of life, look for new ways of making money or find new trade paths. Rosenthal (1990) and Kadlub (1998) said that the perception about education was also changing, as many young people preferred higher education to learning a skill, with the hope of getting better jobs that were less arduous than construction work. Others regard construction trade as dirty and high-risk profession. Offei-Nyako et al. (2014), on the other hand, accredited the shortage of skilled labour to low remuneration and motivation for skilled workers. Due to this trend, young people in Ghana do not have interest in vocational training (Offei-Nyako et al., 2014). What deepens the already precarious situation is the government's free Senior High School (SHS) policy, which aims at providing free secondary education to all Junior High School students. The shortage is really creating a lot of problems for contractors because at the core of performance there is efficient skilled workforce (Bilau et al., 2015; Tshele \& Agumba, 2014). Utting (2009) stated that shortage of skilled labour was taking a toll on the quality of work and creating incessant delays in most construction projects.

One peculiar problem in Ghana which is making the situation worst for most construction companies is the company's inability to train their employees and their fear stems from the fact that such workers can be poached by other construction companies. A survey conducted in America in 2017 revealed that it would be harder to hire in the foreseeable years (Association of General Contractors of America) (AGC, 2017). GIATEC (2019) reports that $80 \%$ of American contractors cannot find skilled workers to employ. Erkelens \& van Egmond-de Wilde de Ligny (2007) posited that some employees in the system also had low skills that often negatively impacted the quality of output. 
Table 4. Rotated Component Matrix

\begin{tabular}{|c|c|c|c|c|c|c|c|c|}
\hline \multirow[t]{2}{*}{ Causes } & \multicolumn{8}{|c|}{ Components } \\
\hline & 1 & 2 & 3 & 4 & 5 & 6 & 7 & 8 \\
\hline Economic change & -0.436 & 0.275 & -0.003 & 0.166 & 0.279 & -0.259 & -0.133 & -0.198 \\
\hline $\begin{array}{l}\text { Union/open shop } \\
\text { changes }\end{array}$ & -0.066 & 0.114 & 0.942 & -0.146 & 0.032 & 0.072 & -0.055 & -0.002 \\
\hline $\begin{array}{l}\text { Educational changes } \\
\text { and images }\end{array}$ & -0.178 & 0.392 & -0.132 & 0.181 & 0.133 & 0.527 & -0.050 & 0.132 \\
\hline $\begin{array}{l}\text { Irregular and low } \\
\text { remuneration }\end{array}$ & -0.094 & -0.021 & 0.137 & -0.094 & 0.060 & 0.760 & 0.050 & 0.096 \\
\hline Low motivation & 0.416 & -0.123 & -0.124 & -0.171 & 0.102 & 0.607 & 0.087 & -0.138 \\
\hline High education level & 0.760 & 0.062 & -0.044 & -0.248 & 0.250 & 0.197 & 0.024 & 0.068 \\
\hline $\begin{array}{l}\text { Increased demand for } \\
\text { craft workers }\end{array}$ & 0.879 & -0.151 & -0.088 & -0.084 & 0.060 & -0.079 & 0.013 & 0.022 \\
\hline Lack of job security & 0.692 & -0.072 & 0.181 & 0.066 & -0.220 & -0.257 & 0.075 & -0.070 \\
\hline $\begin{array}{l}\text { Lack of interest by the } \\
\text { youth }\end{array}$ & 0.059 & -0.019 & 0.958 & 0.001 & -0.079 & -0.043 & -0.022 & 0.015 \\
\hline Ageing workforce & -0.010 & -0.121 & 0.002 & 0.815 & 0.169 & -0.224 & -0.084 & 0.140 \\
\hline $\begin{array}{l}\text { Changes in skill } \\
\text { requirements }\end{array}$ & -0.268 & -0.003 & -0.150 & 0.780 & -0.196 & 0.028 & 0.018 & 0.000 \\
\hline $\begin{array}{l}\text { Dissatisfaction with } \\
\text { labour organisation }\end{array}$ & -0.206 & 0.528 & -0.154 & 0.469 & -0.303 & 0.250 & -0.163 & -0.126 \\
\hline $\begin{array}{l}\text { Geographical } \\
\text { allocation }\end{array}$ & -0.047 & 0.611 & -0.033 & -0.016 & -0.061 & 0.290 & -0.391 & -0.099 \\
\hline $\begin{array}{l}\text { Small number of new } \\
\text { entrants }\end{array}$ & -0.045 & 0.239 & -0.197 & -0.361 & 0.330 & -0.308 & -0.590 & -0.004 \\
\hline $\begin{array}{l}\text { Not meeting employer } \\
\text { expectation }\end{array}$ & 0.016 & 0.114 & 0.031 & -0.022 & 0.890 & 0.137 & -0.059 & 0.024 \\
\hline Poor education & 0.075 & 0.075 & -0.236 & -0.061 & 0.635 & 0.123 & 0.518 & -0.227 \\
\hline $\begin{array}{l}\text { Poor construction } \\
\text { industry image }\end{array}$ & 0.080 & 0.053 & -0.105 & -0.159 & 0.068 & -0.003 & 0.792 & 0.198 \\
\hline High mobility & 0.058 & 0.063 & 0.042 & -0.036 & -0.050 & -0.006 & 0.235 & 0.863 \\
\hline Poor treatment & -0.020 & -0.381 & -0.039 & 0.203 & -0.013 & 0.133 & -0.087 & 0.746 \\
\hline New technology & 0.117 & -0.684 & -0.031 & 0.132 & -0.320 & 0.027 & 0.039 & 0.095 \\
\hline Poor training & 0.040 & -0.786 & -0.149 & 0.054 & -0.038 & 0.149 & -0.216 & 0.030 \\
\hline
\end{tabular}

Extraction method: Principal Component Analysis.

Rotation method: Vari-max with Kaiser Normalization.

Rotation converged in 12 iterations. 


\section{THE EFFECTS OF SKILLED LABOUR SHORTAGE}

Poor quality work was rated as the major effect of skilled labour shortage with an average index of 1.79 as shown in Table 5. This was followed by safety issues with an average index of 1.70. Inability to understand drawings and low labour productivity occupied the $9^{\text {th }}$ and $10^{\text {th }}$ positions, respectively.

Table 5. Effects of Skilled Labour Shortage

\begin{tabular}{lcc}
\hline \multicolumn{1}{c}{ EEFECTS } & AVERAGE INDEX & RANK \\
\hline Poor quality work & 1.79 & 1 \\
Safety issues & 1.70 & 2 \\
Material wastage & 1.66 & 3 \\
Improper construction method & 1.64 & 4 \\
Errors during construction & 1.61 & 5 \\
Additional cost of removing bad work & 1.60 & 6 \\
Slow construction/delay in project duration & 1.57 & 7 \\
Inability to manage unforeseen site problems & 1.56 & 8 \\
Inability to understand drawings & 1.53 & 9 \\
Low labour productivity & 1.45 & 10 \\
\hline
\end{tabular}

\section{Characteristics of Skilled Labour}

The Cambridge Dictionary (2020) describes the word "characteristic" as the features or qualities that make something a part of a place, a group or a person. It is an identifier. In Table 6, determination and persistency were rated as the most important characteristics that are required by every skilled labour. Ability to work in harmony with others came second with an average index of 1.72. However, in-depth knowledge of handling tools and equipment was evaluated as the least skilled labour characteristic.

Table 6. Skilled Labour Characteristics

\begin{tabular}{lcc}
\hline \multicolumn{1}{c}{ Characteristics } & AVERAGE INDEX & RANK \\
\hline Determination and persistency & 1.81 & 1 \\
Ability to work in harmony with others & 1.72 & 2 \\
Flexibility (ease of adaptation to changes) & 1.66 & 3 \\
Honesty & 1.66 & 3 \\
Technical competence & 1.65 & 5 \\
Communication skills & 1.64 & 6 \\
Eager and willing to add to their knowledge base and skills & 1.62 & 7 \\
Excellent reading and analytical skills & 1.58 & 8 \\
Good hand-eye and body coordination & 1.58 & 8 \\
Work ethic & 1.58 & 8 \\
Loyalty & 1.55 & 11 \\
Problem-solving skills & 1.47 & 12 \\
In-depth knowledge of handling tools and equipment & 1.35 & 13 \\
\hline
\end{tabular}




\section{CONCLUSIONS}

The skilled labour shortage in the building construction industry within the Central Region was due to painters and decorators, electricians and tile workers. This shortage was attributed to socio-economic conditions, external forces, job attractiveness, job characteristics, job satisfaction, industry limitations and personal factors. Poor quality delivery and safety related issues were chronicled as the key effects of skilled labour shortage. In turn, relentless determination, ability to work in harmony with others, flexibility (ease of adaptation to changes), honesty, technical competence, communication skills and eagerness and willingness to add to knowledge base and skills were highlighted as the most important characteristics of skilled labour required. To reduce the shortage of skilled manpower, employees should be encouraged and advised to develop their required attitude and competences for their trades. Young people who are technically inclined and talented should be encouraged and motivated by parents and local government agencies to follow their dream. In addition, their minds should be diffused from perceiving the industry as a dirty and high-risk industry. Building construction companies should go a step further to invest in training of people to build their manpower base. Systems should be put in place to retain such workers so that they can enjoy the benefits of the investment.

\section{REFERENCES}

Association of General Contractors of America (AGC). (2017). Seventy-percent of contractors have a hard time finding qualified craft workers to hire amid growing construction demand, national survey finds. Retrieved from https://www.agc.org/news/2017/08/29/seventy-percent-contractors-have-hard-time-finding - qualified-craft-workers-hire-am-0

Ahmed, V., Pathmeswaran, R., Baldry, D., Worrall, L. \& Abouen, S. (2008). An investigation into the barriers facing black and minority ethnics within the UK construction industry. Journal of Construction in Developing Countries, 13(2), 83-99.

Amankwa, O. P. J. (2003). Ghana: A human geography for secondary schools. Ghana: St. Francis Press.

Baloyi, L. \& Bekker, M. (2011). Causes of construction cost and time overruns: The 2010 FIFA World Cup stadia in South Africa. Acta Structilia, 18(1), 51-67.

Barnow, B. S., Trutko, J. \& Piatak, J. S. (2013). Occupational Labor Shortages: Concepts, Causes, Consequences and Cures. Kalamazoo, MI: W. E. Upjohn Institute for Employment Research. https://doi.org/10.17848/9780880994132

Bennett, J. \& McGuinness, S. (2009). Assessing the impact of skill shortages on the productivity performance of high-tech firms in Northern Ireland. Applied Economics, 41(6), 727-37. https://doi.org/10.1080/00036840601007450

Bilau, A. A., Ajagbe, M. A., Kigbu, H. H. \& Sholanke, A. B. (2015). Review of shortage of skilled craftsmen in small and medium construction firms in Nigeria. Journal of Environmental Earth Sciences, 5(15), 98-103.

Cambridge Dictionary. (2020). Meaning of characteristic. Retrieved from https://dictionary.cambridge.org/dictionary/english/characteristic

Carliner, M. (1998). Construction Labour Shortage. Housing Economics, 6-7.

Dainty, A. R. J., Ison, S. G. \& Root, D. S. (2004). Bridging the skill gap: A regionally driven strategy for resolving the construction labour market crisis. Engineering, Construction and Architectural Management, 11(4), 275-283. https://doi.org/10.1108/09699980410547621 
Enshassi, A., Mohamed, S. \& Ekarriri, A. (2009). Essential Skills and Training Provisions for Building Project Stakeholders in Palestine. Journal of Construction in Developing Countries, 14(1), 31-50.

Erkelens, P. A \& van Egmond-de Wilde de Ligny, E. L. C. (2007). Achieving sustainable building education: The case of Polytechnics in Ghana. HEJ: ARC-081226-B, 1-6.

GIATEC. 2019. The Impact of the Labor Shortage in the Construction Industry. Retrieved from https://www.giatecscientific.com/education/the-impact-of-the-labor-shortage-in-the-constr uction-industry

Gudienè, N., Banaitis, A., Banaitienè, N. \& Lopes, J. (2013). Development of a conceptual critical success factors model for construction projects: A case of Lithuania. Procedia Engineering, 57, 392-397. https://doi.org/10.1016/j.proeng.2013.04.051

Healy, J., Mavromaras, K. G. \& Sloane, P. J. (2011). Adjusting to skill shortages: complexity and consequences. Retrieved from https://papers.ssrn.com

Kadlub, L. (1998). Shortage of workers slams area contractors. Retrieved from http://www.ncbr.com/dec97/constr.shortage.htm

Lill, I. (2004). Evaluation of labour management strategies in construction. Tallinn: TUT Press.

Mackenzie, S., Kilpatrick, A. R., \& Akintoye, A. (2000). UK construction skills shortage response strategies and an analysis of industry perceptions. Construction Management and Economics, 18(7), 853-862. https://doi.org/10.1080/014461900433131

NH Business Review. (2018). The skilled labor shortage: causes and solutions. [Accessed February 18, 2020] https://www.nhbr.com/the-skilled-labor-shortage-causes-and-solutions/

Offei-Nyako, K., Osei-Tutu, E., Fugar, F. D. K. \& Adinyira, E. (2014). Skilled artisanal availability in the Ghanaian construction industry. Covenant Journal of Research in the Built Environment, $1(1), 1-9$.

Ofori, G. (2018). Ghana's construction industry, yesterday, today and tomorrow: towards greater professionalism. Maiden Annual Construction Industry Lecture, Accra International Conference Centre.

Olsen, D., Tatum, M. \& Defnall, C. (2012). How industrial contractors are handling skilled labor shortages in the United States. In Proc. 48th ASC Annual International Conference Proceedings, Birmingham.

Oseghale, B. O., Abiola-Falemu, J. O. \& Oseghale, G. E. (2015). An evaluation of skilled labour shortage in selected construction firms in Edo state, Nigeria. American Journal of Engineering Research, 4(1),156-167.

Oseghale, G. E \& Ata, O. (2008). Reasons for delay in building projects: The case study of Edo state Nigeria. The professional builder. Journal of the Nigerian Institute of Building, 81-88.

Othman, A. A. E. (2014). A conceptual model for overcoming the challenges of mega construction projects in developing countries. African Journal of Engineering Research, 2(4): 73-84.

Rasool, F. \& Botha, C. J. (2011). The nature, extent and effect of skills shortages on skills migration in South Africa. SA Journal of Human Resource Management, 9(1), 1-12. https://doi.org/10.4102/sajhrm.v9i1.287

Rosenthal, B. G. (1990). Perceptions and attitudes of young people about the construction industry: A qualitative study. Qualitative Research Services, Potomac, MD.

Sarantakos, S. (2005). Social Research (3rd ed.). Melbourne: Macmillan Education.

Saunders, M., Lewis, P. and Thornhill, A. (2012). Research Methods for Business Students. Harlow: Pearson Education Limited.

Slim Report. (2002). Craft and skilled trades Slim learning theme report skills and learning intelligence module, 52.

Tabachnick, B. G. \& Fidell, L. S. (2007). Using multivariate statistics (5th ed.). Boston: Allyn and Bacon.

Tarnoki, P. (2002). The real world of managing project: 'Soft-side'. 2nd SENET conference in project management, Cavtat, Croatia, 555-559.

Tshele, L. \& Agumba, J. N. (2014). Investigating the causes of skills shortages in South African construction industry: a case of artisans. Retrieved from http://hdl.handle.net/10210/13149

Utting, P. (2009). The risks of skills shortage in construction. Retrieved from http://www.irbnet.de/daten/iconda/CIB_DC22755.pdf 
Ward, P. A. (1979). Organisation and procedures in the construction industry. Great Britain: Macdonald and Evans Ltd.

Willow, T. 1998. Workforce Shortage - now and in the future part I. Retrieved from http://agc-ca.org/low_bandwidth_html/press_14.html

Windapo, A. O. (2016). Skilled labour supply in the South African construction industry: The nexus between certification, quality of work output and shortages. SA Journal of Human Resource Management, 14(1), 1-8.

Yusof, Z. M. \& Misnan, M. S. (2009). Malaysian construction workforce: Whether local youth interested to enroll into training institutions such as Akademi Binaan Malaysia (ABM) to undergo training to be skilled construction workers. In Proc., 2nd International Conference on Construction Industry, Padang.

\section{SHORT AUTHOR'S BIOGRAPHIES}

Benjamin Boahene Akomah is a Senior Lecturer at the Cape Coast Technical University. B. B. Akomah is currently pursuing his $\mathrm{PhD}$ at VIT University in India. He obtained his Master of Philosophy degree in Procurement Management in 2014 from the Kwame Nkrumah University of Science and Technology (KNUST), BSc. in Building Technology from the same university in 2008 and his Higher National Diploma (HND) in Building Technology from the Cape Coast Polytechnic in 2005. He is the co-author of several scientific publications. He is a corporate member of the Ghana Institution of Construction (GIOC - GH) and Institution of Engineering and Technology (IET - GH).

Address: Department of Building Technology, P. O. Box DL. 50, Cape Coast, Ghana.

E-mail: benjamin.akomah@cctu.edu.gh

ORCID: https://orcid.org/0000-0002-2701-2867

Laud Kobina Ahinaquah was a student at the Cape Coast Technical University. He obtained his HND from the Cape Coast Polytechnic and his BSc from the Kwame Nkrumah University of Science and Technology. Currently he is self-employed.

E-mail: ahinaqua2012@gmail.com

Zakari Mustapha $(\mathrm{PhD})$ is a Senior Lecturer. He received his Doctoral degree in Engineering Management in 2017 from the University of Johannesburg, South Africa. He received his MSc degree in Land Resources and Administration in 2000 from Bayero University, Kano, Nigeria and his B. tech. edu. degree in Construction Education in 1992 from the Federal University of Technology, Yola, Nigeria. He is currently with the Cape Coast Technical University (formerly Cape Coast Polytechnic). He is the author and $\mathrm{co}^{-}$author of several scientific publications. He is a cooperate member of the Ghana Institute of Construction (MGIOC) and Incorporate-Chartered Institute of Building (CIOB-UK).

Address: Department of Building Technology, P. O. Box DL. 50, Cape Coast, Ghana.

E-mail: mustapha.zakari@cctu.edu.gh

ORCID: https://orcid.org/0000-0002-0653-8739 